A. Kovtun, V. Tabunenko, A. Parkhomchuk

National Academy of the National Guard of Ukraine, Kharkiv, Ukraine

\title{
THEOREM ABOUT THE CHANGE OF RESONANCE FREQUENCIES OF VIBRATIONS OF MECHANICAL SYSTEMS WITH FRICTION
}

\begin{abstract}
There are the insufficiently known phenomena, resulting in the operating damages of knots and details of machines, among that most dangerous are a friction, wear, and dynamic tiredness. They behaves to the mechanical systems, the elements of that are bound by inter se forces of dry friction, that is widely widespread in a technique, especially in the knots of contact of elements with a friction. It results in the origin of new effects the account of that is needed for providing of increase of reliability of work of machines and mechanisms. At the decision of practical tasks usually use the simplified charts that are characterized the eventual number of degrees of freedom, although the real mechanical system has an endless large number of degrees of freedom. The study of vibrations of the mechanical systems on such models allows to get basic conformities to law of influence of interesting factors on dynamic descriptions of the system. In the theory of vibrations are of interest research of questions of cooperation of forces of friction, operating in the system, and force vibrations. However paid attention to the question of influence of forces of friction on the size of frequency of resonant vibrations of the mechanical systems. Under the inlaid constructions we understand such, when one elements of construction are located into other and here constrained inter se on opposite surfaces by forces of dry friction. The selection of class of the inlaid constructions, among the nonlinear mechanical systems, requires the row of clarifications. Consists the feature of design of one mass models of the inlaid constructions in that they have two degrees of freedom. It results in appearance at the inlaid constructions of new properties, what and dedicated hired.
\end{abstract}

Keywords : mechanical system; degrees the freedoms; inlaid constructions; operating damages; friction; wear; dynamic systems; calculation charts; oscillating mechanical systems; nonlinear mechanical systems.

\section{Formulation of the problem}

One of the problems facing modern science is to ensure the reliability of machines $[1,4]$. Among many phenomena that lead to operational damage to machine components and components, friction, wear and dynamic fatigue are the most dangerous. First of all, this refers to mechanical systems, the elements of which are interconnected by the forces of dry friction. Such systems are widely used in engineering, especially in the nodes of contacting elements with friction [2]. If the contact of the body with the counter body occurs on opposite surfaces (we call such constructions nested), then this leads to the appearance of new effects, which are necessary to ensure the increased reliability of machines.

It is known that a real mechanical system has an infinite number of degrees of freedom. However, when solving practical problems, simplified schemes are usually used, which are characterized by a finite number of freedom degrees. In such calculation schemes, some (the lightest) parts of the system are considered completely devoid of mass and are represented in the form of deformable inertia-free bonds, while the bodies behind which the inertia property is retained in the calculation scheme are considered material points [1]. The study of the oscillations of mechanical systems on such models makes it possible to obtain the basic regularities of the influence of the factors of interest on the dynamic characteristics of the system.

A special place in the theory of oscillations is given to investigations of the interaction of frictional forces acting in the system and forced oscillations. At the same time, this issue is mainly discussed in two aspects: friction, as a source of self-oscillations and oscillations, is a mechanism for controlling friction. As a result, attention is not paid to the effect of friction forces on the frequency of the resonant oscillations of mechanical systems. This is connected, perhaps, with the fact that this issue is considered resolved. However, the selection of a class of embedded constructions (among nonlinear mechanical systems) requires some refinement.

Nested we will call the construction, some elements of which are located inside the others and are connected to each other on opposite surfaces by the forces of dry friction, and the ratio of the maximum tangential force spent on overcoming the bonds caused by touching the elements when removing them from the state of rest to the same load, which compresses the touch elements, provided there is no connection between them on opposite surfaces, greater than the true coefficient of friction of rest.

Nested constructions correspond to a mechanical model of a certain type. The peculiarity of the model lies in the fact that the single-mass model of the embedded construction has two degrees of freedom [2]. This leads to the appearance of new properties in nested constructions.

The aim of the article is to determine the influence of the frictional force on the magnitude of the oscillation frequency of a mechanical system.

\section{The Main material}

Let us consider the effect of friction on the frequency of free vibrations of a single-mass mechanical system, which is a load of mass $m$ suspended on a spring in rigidity $k$, in parallel to which a damping element with a damping coefficient $C$ (Fig. 1). The differential equation of cargo movement, as is known, has the form [3-6]:

$$
m \ddot{x}+c \dot{x}+k x=0 .
$$

The solution of this equation is known: 


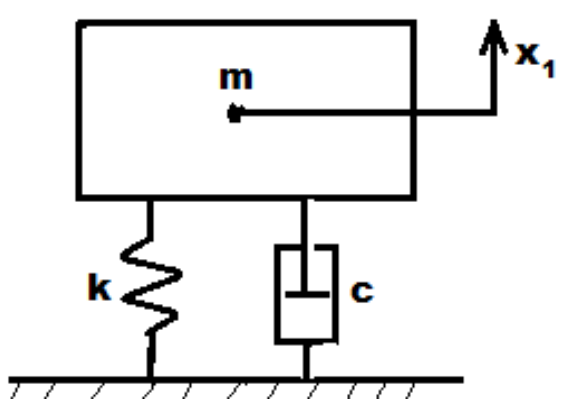

Fig. 1. The calculation scheme of a single-mass model of a mechanical system with one degree of freedom

$$
x=e^{\frac{C t}{2 m}}\left[C_{1} \cos p t+C_{2} \cos p t\right],
$$

here $C_{1}, C_{2}$ are arbitrary constants; $p$ is the frequency of the natural oscillations.

$$
p=\sqrt{\frac{k}{m}-\frac{c^{2}}{4 m^{2}}} .
$$

From the last equality it is seen that with increasing resistance the frequency of the oscillations of the load decreases, which is confirmed by experiments.

We apply the external force $Q(t)=Q_{0} \sin \omega t$ to the load. Let us see how the increase in the damping factor affects the value of the frequency of the resonance oscillations of the load. The resonance in the system will no longer occur when the ratio of the frequency of the forced oscillations to the frequency of the natural oscillations of the system without friction $p$ is equal to 1 , but at lower frequencies, that is, the maxima of the curves of the dynamical system dependence on the ratio $\omega / p$ will be shifted to the left of the value $\omega / p=1$ [6]. Thus, for the system under consideration, an increase in the damping coefficient $C$ leads to a decrease in the value of the frequency of the resonance oscillations of the load. The calculation of a mechanical system consisting of $n$ masses and $n$ dampers is given in [7]. And in this case, an equal increase in the damping coefficients in $n$ dampers leads to a decrease in the magnitude of the frequency of the resonance oscillations of the goods. A further increase in damping leads to an end to the oscillatory movements of the system.

From the definition of this nested construction, it follows that the nested structures correspond to mechanical models of a certain type. One of such models with two degrees of freedom (with one mass and one knot of friction) is shown in Fig 2. A feature of nested constructions is the condition ( $\mathrm{s}$ is the number of damping elements, $n$ is the number of degrees of freedom).

Let us examine, in the general case, the dependence of the natural frequencies of oscillations of a mechanical system on the magnitude of the frictional force. In this case, consider systems in which the number of damping elements is equal $(S=n)$, and less number of degrees of freedom, which corresponds to nested structures.

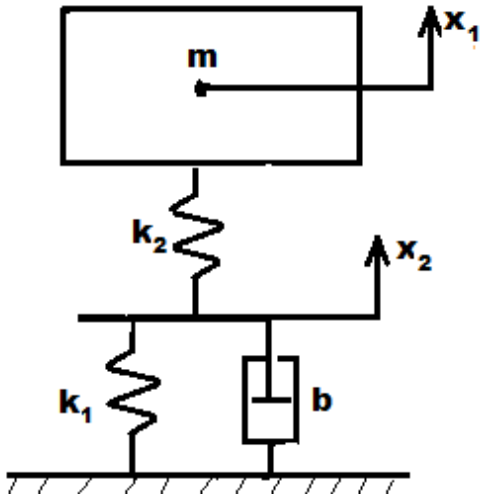

Fig. 2. The calculation scheme of a single-mass mechanical system with two degrees of freedom

Consider the oscillations of a mechanical system consisting of two masses $m_{1}$ and $m_{2}$ (we take $m_{1}=m_{2}=$ $m$ ), connected with the base and each other by means of elastic elements with stiffness $\mathrm{k}$ and damping elements with a damping coefficient $C$ (Fig. 3 ).

We apply to the masses an external force

$$
Q=Q_{0} \sin t
$$

The equations of oscillations of the system have the form [6]:

$$
\begin{gathered}
\ddot{x}_{1}=\frac{k_{3}}{m_{1}} x_{2}-\frac{\left(k_{1}+k_{3}\right)}{m_{1}} x_{1}-\frac{c_{1}}{m_{1}} \dot{x}_{1}+\frac{Q_{0}}{m_{1}} \sin \omega t, \\
\ddot{x}_{2}=\frac{k_{3}}{m_{2}} x_{1}-\frac{\left(k_{1}+k_{3}\right)}{m_{2}} x_{2}-\frac{C_{2}}{m_{2}} \dot{x}_{2}+\frac{Q_{0}}{m_{2}} \sin \omega t .
\end{gathered}
$$

Analysis of the results of calculation of the resonance frequencies of the oscillations of the system under consideration as a function of the value of the damping coefficient (with parameters $m_{1}=m_{2}=m=$ $=1 \mathrm{~kg}, k_{1}=k_{2}=k_{3}=200 \mathrm{n} / \mathrm{m}$ and calculations of many mass systems carried out using numerical methods allow us to formulate the theorem on the change in resonance frequencies of oscillations of mechanical systems in the presence of friction.

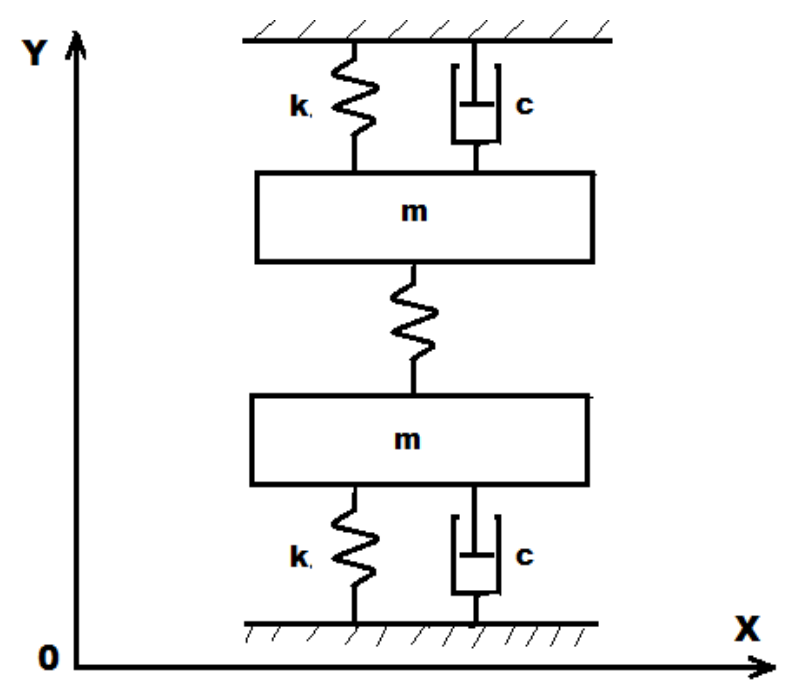

Fig. 3. Design diagram of two-mass mechanical systems with dampers 
Theorem. Introduction to the mechanical system with $\mathrm{n}$ degrees of freedom $\mathrm{s}$ of dissipative elements leads to the fact that the resonant frequencies of the newly formed system with respect to the system without friction are located as follows:

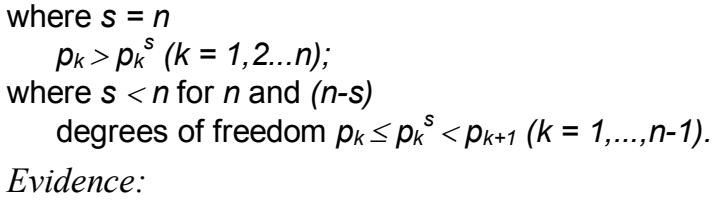

Evidence:

1. Consider a mechanical system in which the number of damping elements is equal to the number of degrees of freedom $(n=s)$. The equation of motion in the system has the form [8]:

$$
M \ddot{X}+C \dot{X}+S X=Q,
$$

where $M$ is the mass matrix; $C$ is the damping matrix; $S$ is the matrix of rigidity.

It was shown in $[6,8]$ that in this case the with equation of motion in normal coordinates will have the form:

$$
\ddot{x}_{i}+2 n_{i} \dot{x}_{i}+p^{2}{ }_{i} x_{i}=q_{i}, \quad i=1,2,3 \ldots n,
$$

where $2 n$ is the damping constant.

Each of the $n$ equations is unrelated to all the others. Therefore, the dynamic displacement is related to the i-th form of oscillations.

The dynamic displacements corresponding to the ith form of the oscillations of the system, in the presence of damping, are determined by the expression [6]:

$$
x_{i}=e^{-n_{i} t}\left(x_{0 i} \cos p_{i} t+\frac{\dot{x}_{0 i}+n_{i} x_{0 i}}{p_{i}} \sin p_{i} t .\right.
$$

The circular frequency with damped oscillations is determined from the expression:

$$
p_{\text {Љ } i}=\sqrt{p_{i}-n_{i}^{2}=p_{i} \sqrt{1-\gamma_{i}^{2}}},
$$

where $p_{i}$ is the circular frequency of undamped oscillations; $C_{i}$ is the corresponding value of the damping coefficient.

Thus, $p_{i}>p_{i s}$.

2. Consider a mechanical system in which the number of damping elements is less than the number of degrees of freedom $(n>s)$. Suppose that the $s_{l}$ damping element is converted into a rigid connection $(\mathrm{C} \rightarrow \infty)$. The coupling equation can be represented by the expression [8]:

$$
\begin{gathered}
A_{11} q_{1}+A_{12} q_{2}+\ldots+A_{1 n} q_{n}=0 \\
\left(a_{11} \cdot p^{2}-c_{11}, a_{12} \cdot p^{2}-c_{12} \ldots a_{1 n} \cdot p^{2}-c_{1 n}\right) ; \\
\left|a_{21} \cdot p^{2}-c_{21}, a_{22} \cdot p^{2}-c_{22} \ldots a_{2 n} \cdot p^{2}-c_{2 n}\right|=0 ; \\
\cdot . . . . . . . . . \\
\left|a_{n 1} \cdot p^{2}-c_{n 1}, a_{n 2} \cdot p^{2}-c_{n 2} \ldots a_{n n} \cdot p^{2}-c_{n n}\right| .
\end{gathered}
$$

The age-old control of the system after imposing a connection on it will be obtained from the first secular equation by deleting the first line and the first column in it. According to the theorem on the separation of the roots of the secular equation, the $n-1$ roots of the $\boldsymbol{p}_{\boldsymbol{k}}{ }^{\boldsymbol{s}}$ of the coupled system are located between the roots of the secular equation of the unrelated system.

Continuing similar arguments, and introducing successively the following relations, we obtain inequalities for the system after imposing all $\mathrm{s}$ bonds on it, that is, $p_{k} \leq p_{k}^{s}<p_{k+1}(k=1,2 \ldots n-1)$.

Thus, depending on the ratio of $n$ and $s$ for the same value of $C$, for each form of oscillation, two values of the resonance frequency of the oscillations of the mechanical system $\omega_{\text {rez }}$ are possible, which converge to the value of $p_{1}$ for $C \rightarrow 0$. The plot of the resonance frequency of the system's oscillations as a function of damping factor for the calculation circuit (Fig. 3, with parameters $m_{1}=m_{2}=m=1 \mathrm{~kg}, k_{1}=k_{2}=k_{3}=200 \mathrm{n} / \mathrm{m}$ ) is shown in Fig. 4.

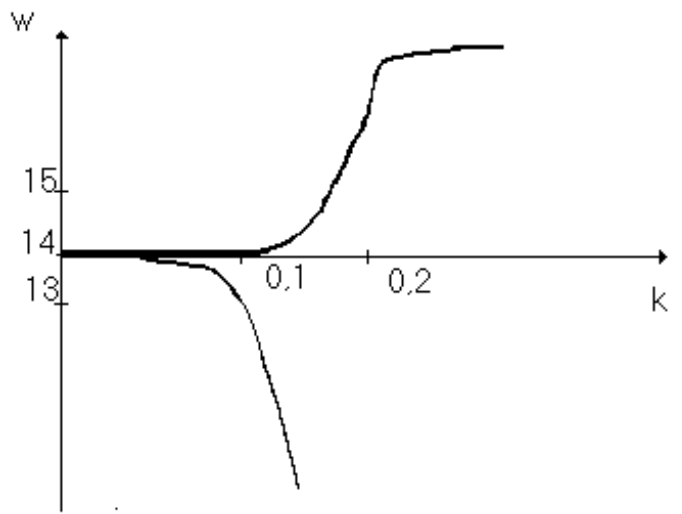

Fig. 4. Graph of the dependence of the resonant frequency of the system oscillations on the value of the damping coefficient

\section{Conclusions}

The properties of oscillatory systems formulated in the theorem are revealed in numerical investigation and can be generalized by the following provisions:

1) The steady-state oscillations occur with respect to the position of stable equilibrium with the frequency of the disturbing force.

2) If the frequency of the perturbing force is close to one of the natural frequencies of the system, then the amplitudes of the oscillations of all masses increase and reach local maxima, the values of which depend on the frictional forces.

3) Local extrema of the resonance curve for $n=s$ are attained at frequencies less than the natural frequencies of the system.

4) Local extrema of the resonance curve $n>s$ are attained at frequencies not less than the natural frequencies of the system.

5) In systems with small friction, the change in the coefficient of friction at any place causes a change in the resonance amplitudes of the oscillations: as the friction increases, the amplitudes decrease. In systems with high friction, it is possible to select a friction value 
at which the amplitude of the oscillations of a certain mass is minimal. The change in friction in the system can lead to the case when the frequency of the resonant oscillations is minimal.

\section{REFERENCES}

1. Den-Gartog, J.P. (1969), Mechanical vibrations, Fizmatgiz, Moscow, 560 p.

2. Kornev, B.G. (1970), Vibration of structures with dry friction between elements, Kharkiv, $176 \mathrm{p}$.

3. Jie, F.Z., Morse, I.E., Hinkle, R.T. and Jie, F.S. (1966), Mechanical oscillations, Mechanical Engineering, Moscow, 508 p.

4. Livitsky, N.I. (1988), Fluctuations in the mechanisms, Science, Moscow, 336 p.

5. Panovko, Ya.G. (1991), Introduction to the theory of mechanical oscillations, Science, Moscow, $255 \mathrm{p}$.

6. Panovko, Ya.G. (1967), Fundamentals of the applied theory of elastic oscillations, Mechanical Engineering, Moscow, $316 \mathrm{p}$.

7. Biderman, V.L. (1980), Theory of mechanical oscillations, High School, Moscow, 408 p.

8. Babakov, I.M. (1964), Theory of oscillations, Science, Moscow, 560 p.

9. Kovtun, A.V., Grekov, V.F. and Prokopov, V.A. (1996), Dynamics of complex mechanical systems with dry friction bonds, Ministr Ministry of Defense of the USSR, Kharkiv, $116 \mathrm{p}$.

10. Kovtun, A.V. (2000), "Features of the dependence of the frictional force of rest of embedded structures on the frequency of vibration exposure", Information Processing Systems, No. 4 (10), pp. 28-30.

11. Encyclopedia of Mechanical Engineering, available at: http://mash-xxl.info/info/264546/ (last accessed January 29, 2018).

12. Lectures on physics. Forced oscillations, available at: physics-lectures.ru/mexanicheski-kolebaniya-i-volny/7-8-vynuzhdennye-kolebaniya/ (last accessed January 29, 2018).

Received (Надійшла) 01.03.2018

Accepted for publication (Прийнята до друку) 25.04.2018

\section{Теорема про зміну резонансних частот коливань механічних систем при наявності тертя \\ А. В. Ковтун, В. О. Табуненко, О. В. Пархомчук}

Існують маловивчені явища, що призводять до експлуатаційних пошкоджень вузлів та деталей машин, серед яких найбільш небезпечними є тертя, знос і динамічна втому. Вони відносяться до механічних систем, елементи яких пов'язані між собою силами сухого тертя, які широко поширені в техніці, особливо у вузлах контактування елементів 3 тертям. Це призводить до виникнення нових ефектів, облік яких необхідний для забезпечення підвищення надійності роботи машин і механізмів. При вирішенні практичних завдань зазвичай користуються спрощеними схемами, які характеризуються кінцевим числом ступенів свободи, хоча реальна механічна система має нескінченну велике число ступенів свободи. Вивчення коливань механічних систем на таких моделях дозволяє отримати основні закономірності впливу цікавлять чинників на динамічні характеристики системи. В теорії коливань становлять інтерес дослідження питань взаємодії сил тертя, що діють в системі, і вимушених коливань. Однак не приділяється увага питанню впливу сил тертя на величину частоти резонансних коливань механічних систем. Виділення класу вкладених конструкцій, серед нелінійних механічних систем, вимагає низки уточнень. Під вкладеними конструкціями розуміємо такі, коли одні елементи конструкції розташовані всередині інших і при цьому пов'язані між собою по протилежних поверхнях силами сухого тертя. Особливість моделювання одномасової моделей вкладених конструкцій полягає в тому, що вони мають два ступені свободи. Це призводить до появи у вкладених конструкцій нових властивостей, чому і присвячується дана робота.

Ключов і слов а: механічна система; ступені свободи; вкладені конструкції; експлуатаційні ушкодження; тертя; зношування; динамічні системи; розрахункові схеми; коливальні механічні системи; нелінійні механічні системи.

\section{Теорема об изменении резонансных частот колебаний механических систем при наличии трения}

А. В. Ковтун, В. А. Табуненко, А. В. Пархомчук

Существуют малоизученные явления, приводящие к эксплуатационным повреждениям узлов и деталей машин, среди которых наиболее опасными являются трение, износ и динамическая усталость. Они относятся к механическим системам, элементы которых связаны между собой силами сухого трения, которые широко распространены в технике, особенно в узлах контактирования элементов с трением. Это приводит к возникновению новых эффектов, учёт которых необходим для обеспечения повышения надёжности работы машин и механизмов. При решении практических задач обычно пользуются упрощёнными схемами, которые характеризуются конечным числом степеней свободы, хотя реальная механическая система имеет бесконечное большое число степеней свободы. Изучение колебаний механических систем на таких моделях позволяет получить основные закономерности влияния интересующих факторов на динамические характеристики системы. В теории колебаний представляют интерес исследование вопросов взаимодействия сил трения, действующих в системе, и вынужденных колебаний. Однако не уделяется внимание вопросу влияния сил трения на величину частоты резонансных колебаний механических систем. Выделение класса вложенных конструкций, среди нелинейных механических систем, требует ряда уточнений. Под вложенными конструкциями понимаем такие, когда одни элементы конструкции расположены внутри других и при этом связаны между собой по противоположным поверхностям силами сухого трения. Особенность моделирования одномассовых моделей вложенных конструкций заключается в том, что они имеют две степени свободы. Это приводит к появлению у вложенных конструкций новых свойств, чему и посвящается данная работа.

Ключевые слова: механическая система; степени свободы; вложенные конструкции; эксплуатационные повреждения; трение; износ; динамические системы; расчётные схемы; колебательные механические системы; нелинейные механические системы. 